\title{
Large Scale Geochemical Signatures Enable to Determine Landscape Use in the Deserted Medieval Villages
}

\author{
Martin Janovskýa, $y^{\mathrm{a},{ }^{*}}$, Jan Horák $\mathrm{k}^{\mathrm{a}, \mathrm{b}}$ \\ ${ }^{a}$ Department of Archaeology, Faculty of Arts, Charles University, Celetná 20, Prague 1, 116 36, Czech Republic \\ ${ }^{b}$ Department of Ecology, Faculty of Environmental Sciences, Czech University of Life Sciences Prague, Kamýcká 129, Praha - Suchdol, 165 00, Czech Republic
}

\section{ARTICLE INFO}

Article history

Received: $2^{\text {nd }}$ June 2017

Accepted: $21^{\text {st }}$ February 2018

DOI: http://dx.doi.org/ 10.24916/iansa.2018.1.5

Key words:

anthropocene

historic land-use

past human impact

multi-element analysis

field pattern

principal component analysis

\begin{abstract}
A B S T R A C T
Medieval settlement activities lead to the enrichment of nutrients in archaeological soils. The fundamental question we ask is whether large-scale mapping of soil horizons can be used to interpret former medieval activities. A portable X-ray fluorescence spectrometer (pXRF) was used to map the content of elements in soils over an area of 104.4 ha at the deserted medieval village of Hol, Czech Republic. Our methods were used to define differences in the geochemical composition of the soil in different parts of the village's residential and field area (as a quantitative part of the research). Additionally we tried to interpret the results in terms of the variability of the natural environment and the medieval village (i.e. a more qualitative interpretational part of the research). Results of XRF spectrometry showed notable differences in element soil composition in different parts of the village. The presence of very low soil $\mathrm{P}$ content is probably caused by ineffective manuring practices in combination with the short duration of the agricultural cultivation. Nevertheless, soil P content helped us to interpret an area of gardens in homesteads IX, X and XI, where the presence of wooden constructions for agricultural purposes is presumed. Agricultural management at the deserted medieval village Hol was connected with organic waste and ash from homesteads (P, Sr, Zn, probably Mn). The spatial distribution of the soil content of elements and PCA allows us to claim that we can differentiate the functional parts of the village based on geochemical methods. At the site of the village we documented deteriorated natural conditions (pedological): for example, the underground water level and eluvial horizons. These conditions could have already been affecting the medieval village Hol. The deserted medieval village Hol does not differ from other deserted medieval villages, where a similar low agricultural fertility is assumed (for example, Kř́i).
\end{abstract}

\section{Introduction}

When studying deserted medieval villages, some light needs to be shed on the relation between human activity and natural environment. Thus the demand on the agricultural production at that time needs to be contrasted with general dispositions of the natural conditions on the sites, as their disparities may have led to the collapse of these settlements. The geochemical methods used in soil surveys can provide some means to gain information on both the human impact and natural conditions.

Soils on archaeological sites can be studied in many ways: macroscopically (Kristiansen, 2001), micromorphologically (Bullock et al., 1985; Lisá et al., 2015) and geochemically.

*Corresponding author. E-mail: mjanovsky@fzp.czu.cz
Some studies are focused on using Phosphorus (Holliday, Gartner, 2007) and there are also studies on using multielement analysis. These studies are mostly focused on the differentiation among archaeological features (houses, fields, hearths etc.), on the verification of human activities, and on analysing the spatial distribution of these activities (Davidson et al., 2007; Nielsen, Kristiansen, 2014; Roos, Nolan, 2012; Wilson et al., 2009). The topic of the spatial extent of activities (e.g. manuring) or land use types (arable field, pastures, meadows, gardens) has also been studied (Entwistle et al., 1998; 2000). In this study, we try to combine the procedures mentioned above to identify the soil environment at the selected site within the context of a chemical reflection of individual parts of the village. However, we mainly focus on multi-element analysis. 


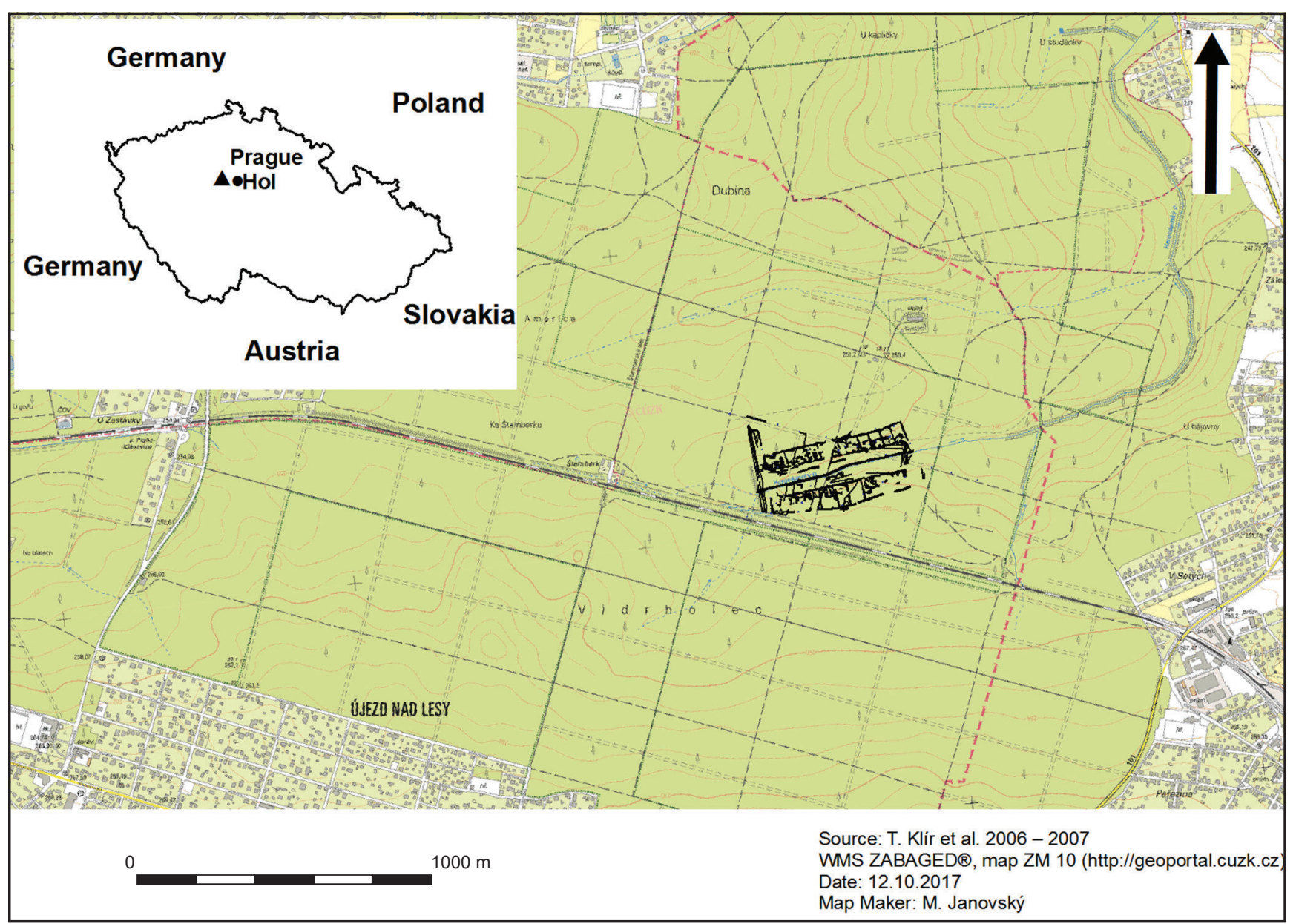

Figure 1. Location of deserted medieval village Hol in the Czech Republic and high resolution map with the position of the study site in the Klánovický Forest. The plan of the deserted village is provided in black on the green background.

Our research is focused on the deserted medieval village of Hol. This output is part of a series of projects focused on the medieval settlement and its transition into the modern era (summary by Klír, 2010a; 2010b). Thematically, it belongs to the interest of European archaeology in the MedievalModern era transition and the processes of social structure development, regional diversity, and economic history (for more comprehensive information, see Klápště, 2016).

In this study, the geochemical compound of soils in the residential and ploughed area of $\mathrm{Hol}$ will be described and interpreted. As the results correspond to the concept of Late Medieval Transition ( $14^{\text {th }}-15^{\text {th }}$ century), the site could be matched to similar localities dating back to between the fourteenth to sixteenth century (Campbell, 2016).

\section{Materials and Methods}

\subsection{Site description}

The deserted medieval village of $\mathrm{Hol}$ is located in the Czech Republic, ten kilometres east of Prague (Figure 1). Apparently, the patricians of the Rokycanští clan founded it in the 1330s or 1340s (Klír, 2016, p. 47). Information from written records, confirmed through an archaeological excavation at the site, give the oldest local pottery as coming from the $14^{\text {th }}$ century (Beránek 2013, pp. 30-40). However, already in 1437, written records described the village of Hol as deserted.

The village centre coordinates are GPS N 50 $5.16977^{\prime}$, E $14^{\circ} 41.84880^{\prime}$. The Horoušánský stream, flowing from west to east, divides the village in half. The village is 14 hectares in area (Beránek, 2011, p. 93). Generally, its former borders may have been shaped by the embankments of the two no-longerexisting ponds of Hol (from the east) and Žák (from the west).

The deserted medieval village of $\mathrm{Hol}$ is a research locality monitored by the Department of Archaeology, Faculty of Arts, Charles University (see Klír, 2016). Its relics have been endangered due to its current forest management and therefore a geodetical survey of the research locality was undertaken and evaluated (Beránek, 2010; 2011; 2013; Janovský, 2015; Klír, Beránek, 2012; Klír, 2013a; Klír, 2013b). Three new clearings were made between 2013 and 2014 , and as a result the relics of the village have been mostly destroyed in this area, which only confirms the threat to the locality. These clearings made a geochemical analysis of the field in the northern half of the village virtually impossible.

The relics of buildings are clearly identifiable, whether they were residential, or farm constructions, as well as walls, 


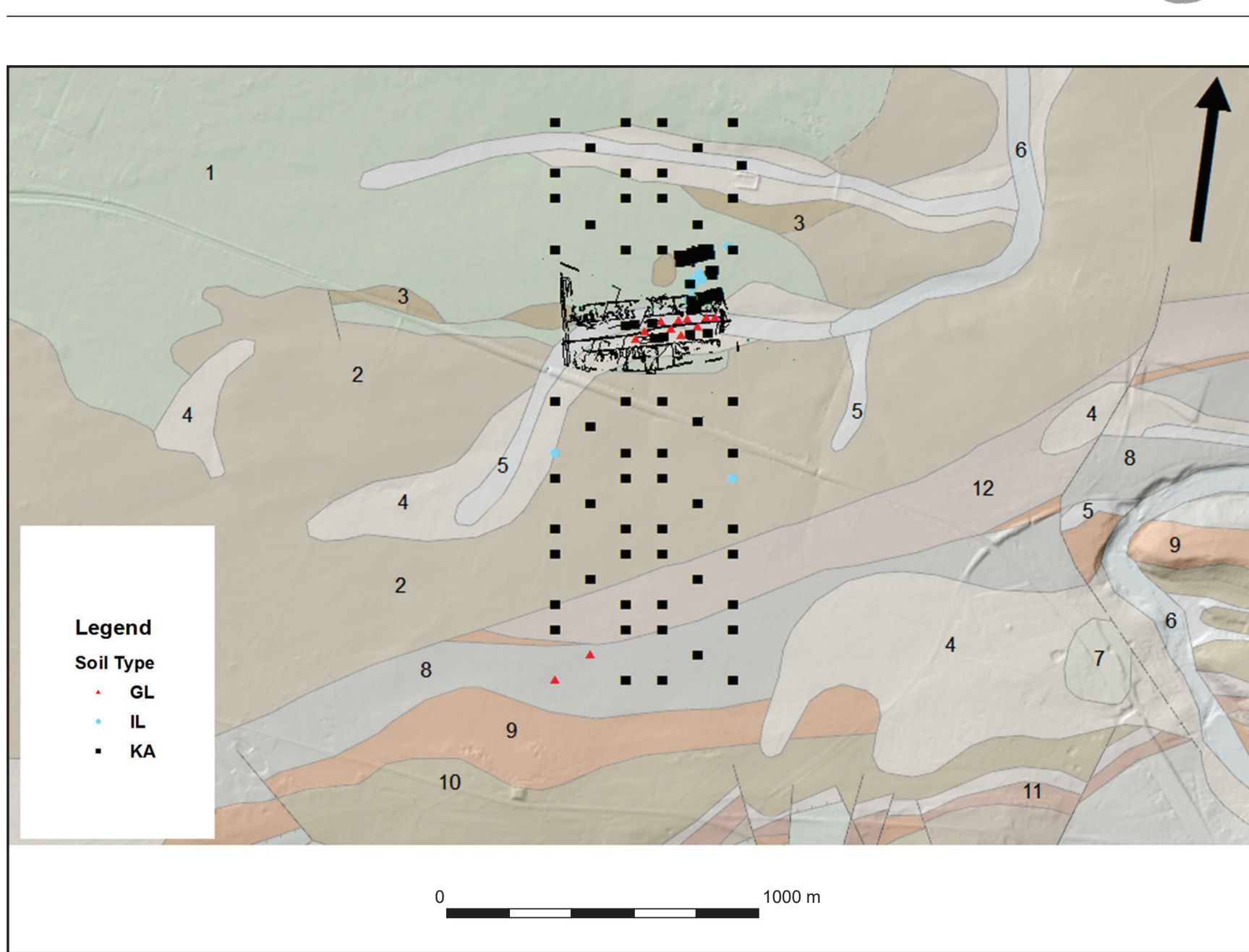

Figure 2. Geological map of the study site (WMS service 2017, http://mapy.geology.cz) with position of the village and indication of soil sampling sites in the former fields. Red triangle indicates gleysol, blue circle illimerized soils and black square cambisols. Numbers: 1 - CRETACEOUS - rock clay, carbonaceous shale, coal, siltstone, sandstone, conglomerate; 2 - PALAEOZOIC BARRANDIEN, bohemikum - wacke, sandstone, siltstone, clay schist; 3 - PALAEOZOIC BARRANDIEN, bohemikum - clay schist; 4 - QUATERNARY - clay-sand or sand-clay sediments; 5 - QUATERNARY - mixed sediment; 6 - QUATERNARY - clay, sand, gravel; 7 - QUATERNARY - aeolian sand; 8 - PALAEOZOIC BARRANDIEN, bohemikum - clay schist; 9-PALAEOZOIC BARRANDIEN, bohemikum - sandstone; 10 - BOHEMIKUM - black shale, iron ore; 11 - PALAEOZOIC BARRANDIEN, bohemikum - flinty shale; 12 - PALAEOZOIC BARRANDIEN, bohemikum - clay schist.

which used to divide yards from garden areas. Twenty-one to twenty-four homestead yards have been documented at the site. They were situated along the northern and southern side of the village common, which was $470 \times 91$ metres in area (Beránek, 2011, p. 110). The parcels were uniformly sized, from 40 to 42 meters each. The northern row of yards is particularly homogenous, whereas the plots in the southern row differ, some being extremely large compared to the northern yards (Beránek, 2011, pp. 110-118).

\subsection{Geomorphology and geology}

The deserted medieval village is placed between 248 and 252 metres above sea level. It is situated at the geomorphological border of the Čakovická tabule and Úvalská plošina, which explains the different characteristics of the two halves of the village (Cháb et al., 2007; Demek, Mackovčin et al., 2006, pp. 136 and 528).

The geological disposition of the site is displayed in Figure 2. The bedrock consists of Ordovician sandstone, siltstone and clay schist. These rocks prevail in the southern part of the research area. The northern part mainly consists of Cretaceous rock clay, carbonaceous shale, coal, siltstone and sandstone. Quaternary sediments were found mainly along streams, consisting of sand-loamy, loamy-sand and fluvial sediments; there were also Aeolian sands in the southern part of the research area.

From a geomorphological point of view, the site is mostly flat, the only exceptions being the valley of the Horoušánský stream, path notches and the embankments of the ponds. The northern side of the field area descends towards the stream and finishes with a marked terrace. The long-lost pond of Žák turned into the basis of a flood fringe. At the former village common of Hol, the flood fringe reached approximately fifty centimetres below the surrounding terrain. The terraces surrounding the fringe start at an altitude of 250 metres followed by the field area where probes showed the altitude to be up to 252 metres. Spirhanzl-Duriš (1929, pp. 125126) thoroughly compiled the agricultural potential of the 


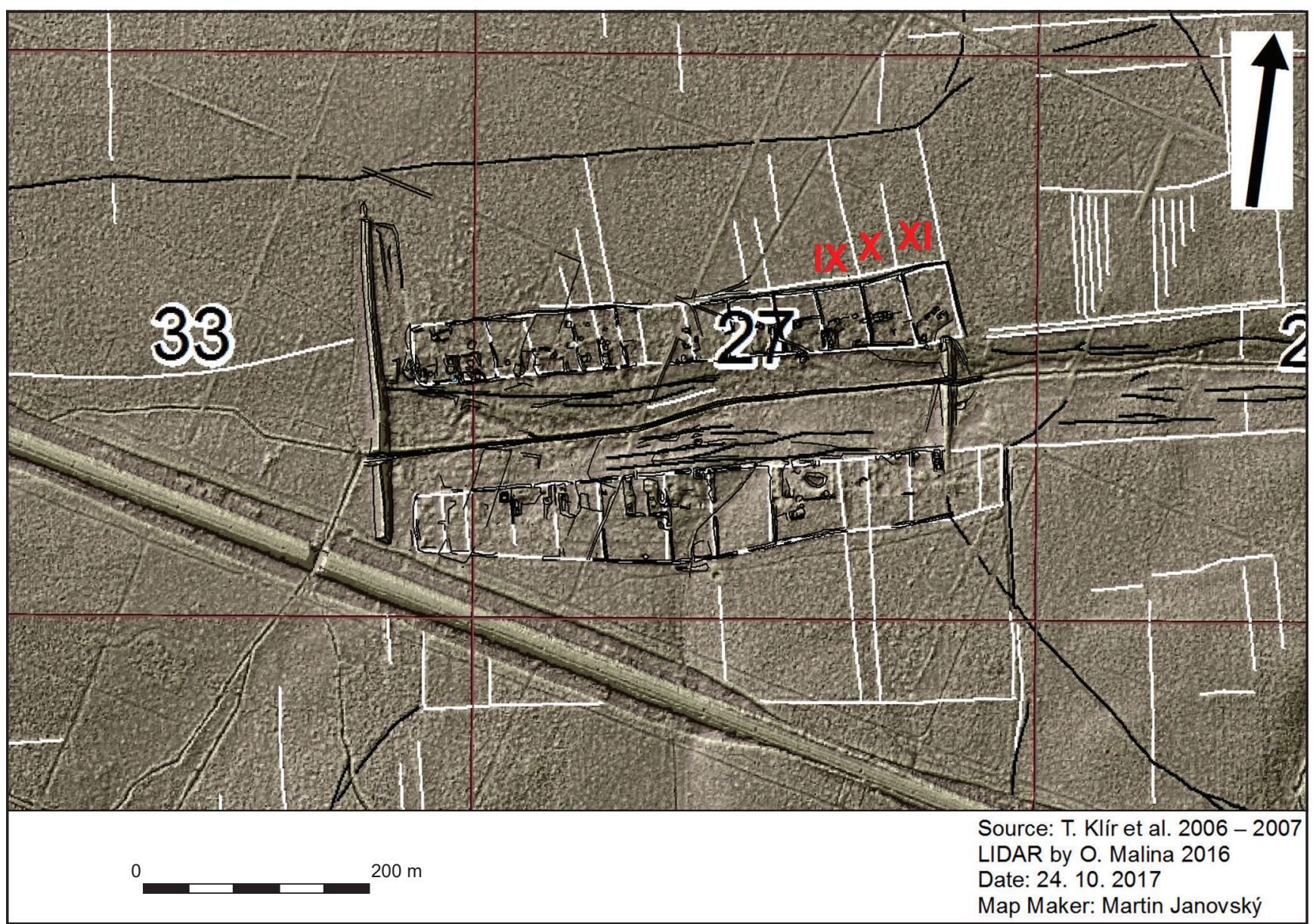

Figure 3. LIDAR map of the intravilan ("within village") of studied deserted village. White lines represent parcel boundaries and terrain edges. The black line indicates the boundaries of the intravilan, the boundaries of farms and their internal division. Arabic numbers indicate map squares and Latin numbers indicate the studied homesteads (according to Beránek 2011, p. 115).

soils in the area. In this study, we add new information gained through site observations and drill holes (Figure 2). Spirhanzl-Duriš pointed out that in the southern part of the field area the soil was easily permeable. In some places, the zone of saturation was as little as $0.5 \mathrm{~m}$ under the topsoil. Therefore, the complete field area in the southern part is now drained, as the forest accumulates a lot of water on the bedrock.

The map of soils (Tomášek, 1990) indicates that the site is underlain with Carbonate Pelosol (according to the Czech taxonomy of soils; Cambisols by WRB 2006; Inceptisols by Soil Taxonomy 1999 of USDA), and so is the Horoušánský stream with brown gleysols. When making the drill holes, we observed that Cambisols (by the Czech Taxonomy and WRB, Inceptisols by USDA) prevail. They consist of a couple of centimetres deep $\mathrm{O}$ horizon, five-centimetre thick A horizon, and B horizon that reached a depth of twenty to thirty centimetres from the surface. The grains are mostly composed of clay-silt or silt. Illuviation is present in the Gleysols (by the Czech Taxonomy and WRB; Aquepts Inceptisols by USDA) near the embankment of the old pond, but is rather rare in comparison to the rest.

Quitt's classification places the microregion in the warm area MT2 (MW2 according to Tolasz et al., 2007), which is specific by its long, warm, and dry summer. Intermittent seasons are very short; spring and autumn are warm or mildly warm. The winter is short, mildly warm, dry, or very dry. The area can be climatically compared to Polabí, Žatecká plateau, Poohř́ and the Mostecká basin (Quitt, 1971, p. 14). The microregion is agro-climatically located at the borderline of a rather warm area and a rather dry district. Although the climatic conditions at the location may not be as favourable as in the fertile lowland in Polabí, they still are among the best in Bohemia (Kurpelová, Coufal, Čulík, 1975, p. 251). MT2 (MW2) areas cover $24.2 \%$ of the Czech Republic; warm areas in total cover 25.1\% (Květoň, Voženílek, 2011, p. 7).

There are fifty to sixty summer days in MT2. Average annual air temperature is $8-9{ }^{\circ} \mathrm{C}$, which corresponds to the average temperatures in most of Polabí, Lower Povltaví, Posázaví and a large area of Poohří (in most lowlands along the rivers Labe, Vltava, Sázava and Ohře). Average annual precipitation reaches $550-600 \mathrm{~mm}$ and the sunshine averages 1600-1700 hours a year (Tolasz et al., 2007, pp. 24-25, pp. 68-69 and 166).

\subsection{The research area}

The research was undertaken over a rectangular area with a dimension of $1800 \mathrm{~m}$ and $580 \mathrm{~m}$. In total, 60 probes were 
placed in the north and south field areas. They were divided into six rows to cover the largest area possible. We used a basic square model with an additional probe placed in the middle of the square. The area of the former pond Žák was included, where we placed 16 probes following the same square model. The geomorphological terraces were chosen as a border on both the southern and northern sides of the area. The last row of probes was situated on the top of the naturally-formed terraces, so that a comprehensive picture of the field area of the deserted medieval village of Hol could be obtained.

Obviously, getting information about the presence of the elements monitored around the village centre was important, so 52 probes were placed in the areas close to the three former houses, their gardens and related field areas.

\subsection{Research design}

The geochemical research of the soils in the area of the village was undertaken twice. In 2015, the first research focused on the geochemical differences in the gardens, surrounding (up to $100 \mathrm{~m}$ ) fields, and the more distant (more than $150 \mathrm{~m}$ ) fields. Samples were taken in three homesteads (homesteads No. IX, X and XI as numbered by Beránek, 2011, p. 115), which are positioned side by side in the NE part of the residential area (see Figure 3). Also, the area of the yard was sampled in farmstead IX. The sampling was designed as following: five probes were placed in the corners and the centre of a square covering the area of the whole garden. This model was also used in the yard and the fields. The size of each farmstead determined the size of the squares, but none significantly exceeded $10 \times 20$ metres. The homesteads were chosen to avoid differences in bedrock which is particularly dynamic on the site. For further comparison, more probes were made: for example, in a former pond (Bakkevig, 1980, p. 75).

In 2016, the second research focused on the deserted medieval fields. The research area, chosen to the north and to the south of the village, is most likely only a part of the whole field area. LIDAR data confirmed that the area researched was used in medieval times. A grid of spots was placed so that it covered the cultivated area at its full length, directly from the homestead walls to the end of the fields at the natural terraces, this area being clearly delineated through the LIDAR data, as well as directly seen in the terrain. We omitted the residential area and the railway corridor in the grid of spots. The research area is marked by the terraces and is thus not regular. Altogether 76 probes were made. The grid is drawn in Figure 2.

The sampling design was based on the mechanical layers with samples being taken in 5-10, 15-20 and 25-30 cm of depth. We focused on the presence of gleyic processes and the $\mathrm{E}$ horizon in the soil profile of probes.

\subsection{Analytical and statistical methods}

The samples were dried (in $40{ }^{\circ} \mathrm{C}$ for 10 hours) and sieved. The fraction under $2 \mathrm{~mm}$ was then analysed. We used a portable ED-XRF (PXRF) analyser Delta Professional by
Olympus InnovX with the Soil Geochem measurement mode to analyse the samples (for applications of XRF spectrometry, see Canti, Huisman, 2015; Hürkamp et al., 2009; Kalnicky, Singhvi, 2001; Šmejda et al., 2017). It should be mentioned that the method we used obtains almosttotal concentrations of elements in the sediment compared to the most used methods that mainly work with near-organicavailable fractions. However, some studies have used neartotal concentrations successfully (Entwistle et al., 1998; 2000; Wilson et al., 2005). All samples were irradiated for one minute $-30 \mathrm{~s}$ of $10 \mathrm{kV}$ beam and $30 \mathrm{~s}$ of $40 \mathrm{kV}$ beam. The used PXRF model provides us with data in weight ppm. The quality of the device results was successfully tested by BAS Rudice Ltd. (www.bas.cz) on 55 reference materials (e.g. SRM, 2709a, 2710a, 2711a, OREAS 161, 164, 166, RTC 405, 408). Each sample was tested five times; the final value is the arithmetic average of the five results.

To obtain more input data, we decided to analyse the data from both seasons together - the collection of 363 samples. We measured 38 elements (basic pXRF analyser setting). Due to some limitations of the measuring device, not all elements reached the limit of detection in all samples. Therefore, we have chosen these elements for the analyses of concentrations: Al, Si, P, K, Ti, Cr, Mn, Fe, Ni, Cu, Zn, As, Rb, Sr, Zr, Pb, Th and LE (light elements - i.e. overall concentration of elements from $\mathrm{H}$ to $\mathrm{Na}$, which are not recognizable separately due to the limitations of the measuring device). We also used principal component analysis (PCA). We chose for it those elements which had reached the limit of detection in a suitable number of cases. The element with the least number of successful measurements was P with 163 cases (Table 1). Missing values of these elements were replaced by a half of the minimum detected value for each element.

We did not test all elements because their limits of detection in samples differ. We used ilr-transformed data of the original concentrations for further analyses (Reimann et al., 2008). The abbreviation "ilr" stands for isometric logratio transformation, which should be used while analysing data of a compositional character (Reimann et al., 2008; Reimann et al., 2012). We used R version 3.4.1 for principal component analysis (PCA) and for spatial visualization of the transformed data (R Core Team 2017). R worked with packages gstat (Pebesma, 2004), raster (Hijmans, 2016) and robCompositions (Templ et al., 2011).

\section{Results}

\subsection{Concentrations, spatial distribution of elements}

An important finding is: how many times was the element measured (Figure 58 and Table 1 in electronic supplementary material - SOM). Al, Si, K, Ti, Fe, Zn, As, Rb, Sr, Zr and LE were measured in every case. By contrast, elements such as $\mathrm{Mg}, \mathrm{S}, \mathrm{Cl}, \mathrm{Ca}, \mathrm{Co}, \mathrm{Se}, \mathrm{Y}, \mathrm{Mo}$ and precious metals were under the limit of detection of the $\mathrm{pXRF}$ used. The values of $\mathrm{P}$ content and its spatial distribution were surprising, since it was measured in only 163 samples and therefore was under the 
Table 1. Summary statistical description of selected measured elements. Length stands for the total number of samples, count for successfully measured samples, and NAs for unsuccessfully measured samples leading to blank cells in the table of measurements. The elements are presented in weight \%.

\begin{tabular}{lcccccccccccccccccc}
\hline Measures & Areal & $\mathbf{A l}$ & $\mathbf{S i}$ & $\mathbf{P}$ & $\mathbf{K}$ & $\mathbf{T i}$ & $\mathbf{C r}$ & $\mathbf{M n}$ & $\mathbf{F e}$ & $\mathbf{N i}$ & $\mathbf{C u}$ & $\mathbf{Z n}$ & $\mathbf{A s}$ & $\mathbf{R b}$ & $\mathbf{S r}$ & $\mathbf{Z r}$ & $\mathbf{P b}$ & $\mathbf{T h}$ \\
\hline Length & all & 363 & 363 & 363 & 363 & 363 & 363 & 363 & 363 & 363 & 363 & 363 & 363 & 363 & 363 & 363 & 363 & 363 \\
Count & all & 363 & 363 & 163 & 363 & 363 & 325 & 361 & 363 & 294 & 362 & 363 & 363 & 363 & 363 & 363 & 362 & 333 \\
NAs & all & 0 & 0 & 200 & 0 & 0 & 38 & 2 & 0 & 69 & 1 & 0 & 0 & 0 & 0 & 0 & 1 & 30 \\
Max & all & 10.79 & 34.4 & 0.25 & 2.92 & 0.88 & 0.02 & 0.33 & 26.15 & 0.02 & 0.01 & 0.03 & 0 & 0.02 & 0.06 & 0.05 & 0.01 & 0 \\
Mean & all & 6.48 & 27.81 & 0.05 & 1.61 & 0.61 & 0.01 & 0.04 & 2.41 & 0 & 0 & 0 & 0 & 0.01 & 0.01 & 0.03 & 0 & 0 \\
Sdev & all & 1.12 & 4.35 & 0.04 & 0.33 & 0.1 & 0 & 0.04 & 2.1 & 0 & 0 & 0 & 0 & 0 & 0.01 & 0.01 & 0 & 0 \\
Median & all & 6.43 & 28.77 & 0.04 & 1.6 & 0.63 & 0.01 & 0.03 & 1.92 & 0 & 0 & 0 & 0 & 0.01 & 0.01 & 0.04 & 0 & 0 \\
MAD & all & 0.96 & 3.8 & 0.02 & 0.25 & 0.08 & 0 & 0.03 & 0.61 & 0 & 0 & 0 & 0 & 0 & 0 & 0.01 & 0 & 0 \\
Min & all & 3.67 & 9.62 & 0.02 & 0.43 & 0.23 & 0.01 & 0.01 & 0.68 & 0 & 0 & 0 & 0 & 0 & 0 & 0.01 & 0 & 0 \\
\hline
\end{tabular}

Table 2. Eigenvalues and explained variability of PCA. The results for the first seven components explained almost $95 \%$ of variability. Only PCs with an absolute value greater or equal to 0.3 are presented. For all PCs and values, see ESM.

\begin{tabular}{|c|c|c|c|c|c|c|c|}
\hline & Comp. 1 & Comp. 2 & Comp. 3 & Comp. 4 & Comp. 5 & Comp. 6 & Comp. 7 \\
\hline \multicolumn{8}{|l|}{$\mathrm{Al}$} \\
\hline \multicolumn{8}{|l|}{$\mathrm{Si}$} \\
\hline $\mathrm{P}$ & -0.42 & -0.84 & & & & & \\
\hline \multicolumn{8}{|l|}{ K } \\
\hline \multicolumn{8}{|l|}{$\mathrm{Ti}$} \\
\hline \multicolumn{8}{|l|}{$\mathrm{Cr}$} \\
\hline $\mathrm{Mn}$ & -0.69 & 0.51 & -0.36 & & & & \\
\hline $\mathrm{Fe}$ & & & & & & & 0.49 \\
\hline $\mathrm{Ni}$ & & & 0.6 & -0.46 & 0.45 & -0.31 & \\
\hline $\mathrm{Cu}$ & & & & & & & 0.34 \\
\hline $\mathrm{Zn}$ & & & & & & & 0.47 \\
\hline As & & & & 0.31 & & -0.45 & \\
\hline \multicolumn{8}{|l|}{$\mathrm{Rb}$} \\
\hline $\mathrm{Sr}$ & & & 0.39 & 0.48 & -0.49 & & \\
\hline \multicolumn{8}{|l|}{$\mathrm{Zr}$} \\
\hline $\mathrm{Pb}$ & & & -0.34 & & & -0.47 & \\
\hline Th & 0.37 & & & -0.58 & -0.52 & -0.31 & \\
\hline
\end{tabular}

limit of detection in the other samples. The limit of detection of $\mathrm{P}$ is usually between 250 to $300 \mathrm{ppm}$ (based on our experience with the results of the device we used). We would have expected higher values in a deserted medieval village.

The type of distribution is an important indicator to define the anthropogenic influence on a soil (Nolan, Redmond, 2015). Here we describe the most common. A normal-like distribution refers to Al, As, K, LE, Pb, Rb. A bimodal distribution refers to $\mathrm{Cr}, \mathrm{P}$, and Th. Skewed normal distribution is the most common and refers to $\mathrm{Cu}, \mathrm{Fe}, \mathrm{Mn}$, $\mathrm{Ni}, \mathrm{Si}, \mathrm{Sr}, \mathrm{Th}, \mathrm{Ti}, \mathrm{Zn}$ and $\mathrm{Zr}$ (See the figures in SOM).

The elements can be divided into several groups by their spatial distribution of content. The first group is characterised by their accumulation in the "intravilan" ("within the village" - a built-up area) and the village common $(\mathrm{Cu}, \mathrm{Fe}, \mathrm{Ni}, \mathrm{P}, \mathrm{Pb}$ and $\mathrm{Zn}$, - Figures $13-18,28-36$ and $52-54$ in SOM). The second main group of elements is spatially manifested in the field area (LE, Mn, Sr - Figures $22-27$ and 43-45 in SOM). The third group consists of those elements that are without any obvious pattern (Al, As, Cr, K, Rb, Si, Th, Ti, Zr, - Figures 4-12, 19-21, 37-42, 46-51 and 55-57 in SOM).

Furthermore, we can comment on the significant spatial relationships. The higher phosphorus $(\mathrm{P})$ content is not only within the village common, but also in the homesteads and adjacent gardens (homesteads IX, X and XI in Figures 3 and 31 in SOM). This content was measured only at a depth of 15-20 cm. Light Elements (LE) make up an interesting spatial pattern in the northeast of the site. The pattern covers the area of homesteads, gardens, and adjacent field pattern (Figures 22-24 in SOM). 


\subsection{PCA}

The PCA extracted 17 principal components (PCs); for the results, see Table 2 and Figures 59-75 in SOM. The first four components explained almost $80 \%$ of the variability; the first eight components explained $95 \%$ of variability. PC1 influenced $\mathrm{Mn}$ and $\mathrm{P}$; it was placed mainly in the village common, in the northeast from the village and around homesteads IX, X and XI (Figure 59 in SOM). PC2 (Figure 60 in SOM) influenced Mn positively and P negatively. Negative values of PC2 were spatially distributed in the centre of the village. $\mathrm{PC} 3$ influenced $\mathrm{Ni}$ positively and $\mathrm{Pb}$ negatively. This component was accumulated in the centre of the locality at the village common (Figure 61 in SOM). The spatial patterns of PC4 and PC5 (Figures 62 and 63 in SOM) differed along a north-south gradient (Mn, Ni, Th, LE, Pb).

\section{Discussion}

A geochemical signal could have either a natural or an anthropogenic origin - and the results from PCA can be interpreted in those terms. However, we need to consider several conditions. Our following interpretation relates to two cases: a) we can associate the results with known anthropogenic indicators; b) we can connect the spatial distribution of an element's content to anthropogenic features. The first case would usually need a contribution from more methods to prove (or at least corroborate) anthropogenic origin. As we worked only with one basic method (pXRF: obtaining total concentrations of elements), we used the second case as a supportive factor for determining the possible anthropogenic origin of geochemical signals. It was the spatial connection to the medieval village. To refine our interpretation, we used PCA - as it could distinguish different inputs hidden within the total elements content in soil (e.g. Entwistle et al., 1998; Horák, Klír, 2017; Horák et al., 2018).

\subsection{Elements and PCs interpreted in context to medieval activities}

There were three groups of elements: a) accumulated in the intravilan (built-up area) and the village common, where they were manifested by their highest content; b) elements with their manifestation in the field area; c) elements without an obvious pattern; however, in some cases indicating human activities.

The first group ( $\mathrm{Cu}, \mathrm{Fe}, \mathrm{Ni}, \mathrm{P}, \mathrm{Pb}$ and $\mathrm{Zn}$ ) can be interpreted as being the result of former human activities that led to an enrichment of the soil content (Entwistle et al., 1998; 2000).

The second group (LE, Mn, Sr) can be interpreted as the result of former human activities, as well as being a result of geology and the underground water level in the case of $\mathrm{Mn}$ (Aston et al., 1998, p. 474; Heršt, 1956; Horák et al., 2018, p. 19).

The third group consists of those elements that are without obvious pattern (Al, As, Cr, K, Rb, Si, Th, Ti, Zr). The last two groups can be interpreted using the PCA analysis.

The higher content of $\mathrm{Mn}$ in soil samples was localised just within the village common. We presume that the content of $\mathrm{Mn}$ was affected by the pond that formed after the abandonment of the village. However, PC1 and PC2 both show correspondence with $\mathrm{Mn}$. It seems that the presence of $\mathrm{Mn}$ in the intravilan is affected by both the geology (PC1) and former medieval activities (PC2). Many studies have proved that $\mathrm{Mn}$ content in soils comes from organic matter or organic waste, including manure (e.g. Nielsen, Kristiansen, 2014; Wilson et al., 2008). The presence of Mn in the area of the fields with a north-south gradient is a reflection of the geology (PC1).We have to also consider the underground water table, which was higher in the part of the northern field, where Quaternary fluvial sediment of a former stream is situated (see Heršt, 1956 and the high concentration of Mn in underground water; Figure 2).

Strontium content differed at the deserted village Hol. The intravilan of the site and the northern part of the intravilan were enriched with Sr (Figures 44 and 45 in SOM). This element could be derived from bones and be connected with the weathering of the soil. Some studies showed that $\mathrm{Sr}$ is present in ancient houses and in the area of abandoned arable fields (Wilson et al., 2005; Nielsen, Kristiansen, 2014, p. 396). However, at Hol, Sr showed significant geological differences between the northern and southern part of the village. The anthropogenic factor of $\mathrm{Sr}$ can be seen in PC3 (intravilan and built-up area of Hol).

$\mathrm{Zn}$ is usually connected to agricultural activities. The presence of Zn relates to the soil environment (Klimek, 2002), the organic matter in the soil as a product of agriculture/ horticulture (da Costa, Kern, 1999), archaeological features (Linderholm, Lundberg, 1994; Wilson et al., 2006), burning (as part of ash - Nielsen, Kristiansen, 2014), and manuring (Wilson et al., 2005; 2009). The $\mathrm{Zn}$ content in soil is increased in the vicinity of ancient buildings (Lewis et al., 1993). At Hol, this element was found at homesteads, gardens, and the village common (PC1, PC3). Ash and organic parts were deposited in those areas, leading to the enrichment of the soil.

We use descriptions like "higher" and "lower" $P$ content in the text below - these descriptions are only relevant within the context of the studied area of Hol. P content levels in the garden area of the northern part of the village do not differ greatly from each other, but with some exceptions (PC2). The measured values are rather high in comparison to the surrounding areas, which might indicate the possible presence of high agricultural buildings of a wooden construction (see evidence of stalls in the deserted medieval village of Svídna; Smetánka, 1988, p. 105).

Though P was identified in the soil, this was only in some parts of the centre of the village. The high P content in the ruins of a stone wall in homestead IX is most likely the outcome of past human activity. Areas at a greater distance from the village display only a negligible content of phosphorus, thus raising the question of how much the medieval fields were fertilized, or whether they were fertilized at all.

The hypothesis of the presence of some mainly-wooden constructions is, at present, just an interpretation resulting from the geochemical survey, which shows a surprisingly high 
P content in comparison to the rest of the site. Geochemistry carries the potential to identify their presence. But a fuller execution of the research would need some different parameters to identify the exact position of the constructions: such as increasing the density of the grid or the application of different methods; for example, the extrusion of the available fraction. Interesting results might also be reached through a content analysis and identification of organic substances, for example, lipids. However, we have not tried to verify the hypothesis through excavation, an obvious method which would provide the information needed with absolute certainty, because it would be a different type of research and would be too invasive for our purposes.

The use of pXRF has raised the question of the analysis validity. Our approach is supported by the results at Tel Burna (Šmejda et al., 2017), where the results were obtained from samples collected in the field, measured directly by the same pXRF we used and then independently measured by ICP-OES from an aqua regia solution. High correlation $(r>0.81, p<0.01)$ was found between the two sets of data. We were aware of signal interference between the elements and the sample matrix effect; however, this effect does not affect the ability of pXRF to measure samples precisely (Šmejda et al., 2017, p. 71).

\subsection{Historical interpretation}

Soil tillage in the village of $\mathrm{Hol}$ can be compared to systems of cultivation in villages with similar soils and environmental dispositions. Tomáš Klír has researched such sites around Nymburk. Unlike the deserted village of Kří (now covered by the forest Kersko), there are the four villages of "Lhota": Kostelní, Písková, Přední, Vrbová. These villages are still inhabited (Klír, 2008, p. 39). The field pattern of the majority of Lhotas was "Gewannflur" (German "village corridor") with a partial continuity of the Záhumenice principle. Gewannflur is a system where the ground is divided into several units, which are further divided into narrow plots. These units are not directly related to the economy of a homestead. In the Záhumenice principle, the ground is divided into long strips across the cadastral territory. The arable fields covered almost the whole area of the agricultural ground of the villages. The basic unit then in use in agriculture was a long strip, which took maximum advantage of the otherwise minimal variability of natural conditions (Klír, 2008, p. 81).

It seems that this system of agriculture works in places with high quality soil (chernozems in Polabí), and eventually - allows time for some forms of modification, such as the fertilisation of unproductive plots. But the strategy appears inefficient in sites with worse conditions (e.g. aeolian sands in the Nymburk area, illuviation around Hol). When a crisis comes, the production of manure is sharply reduced on such sites and thus the material that could help balance the soil quality is missing. This is supported by the fact that not all plots were inhabited at the same time, which means the whole field area was never used completely simultaneously. Given the bad soil quality, this must have led to a poor agricultural harvest in some years.

Based on analogies to the Nymburk area (see Klír, 2008), we deduce that an agricultural system of Gewannflur without meadows was used. This system could not work with the sandy soils, poor in mineral content, of Hol and neither could it work in the other deserted villages in the Nymburk area (Klír, 2013a, pp. 153-154). Other villages in the area adapted to the soil conditions by fallowing for longer periods as well as downsizing the number of homesteads. This adaptation was successful, as they were not deserted during the Middle Ages. Concerning the elements in the soil, Hol can be compared to the Kří site, where a near-to-sterile condition of the soil has also been geochemically confirmed (Hejcman et al., 2013, p. 657; Klír, 2013a, p. 154). The lower soil quality and yields, the lower the number of cattle and thus also the manure. The greater the area of more sterile ground, the less the ground could be fertilised, and the threefield system applied (Klír, 2008, p. 34). As successful as it was elsewhere, the light sand soils around Sadská did not provide enough fertility to use the three-field system, which was reflected in the fluctuations in intensity of use with fallow systems in the field areas (Klír, 2008, p. 35). A similar process probably led to the decline of Hol.

Written sources are able to inform us about the shape of the village and how it functioned. The names of villages could have been derived as much as from the conceptions of the inhabitants of neighbouring settlements and how they perceived the place as anything else. They named the villages after the people or the conditions of the surrounding area. The name of "Hol" indicates a barren place. Even the name might indicate a problem with its settlement or the village's later use. There is a high number of places called Hol in Bohemia and a general, yet clear, link to their agricultural and environmental problems has been confirmed (Profous, 1947, pp. 586-587).

And last, but not least, we observed the presence of an E horizon. In Hol, a white soil E horizon was observed in probes from the northern part of the village, which confirms illuviation and podsolic processes. Under certain circumstances, cultivation with the plough can prevent a delay in the production of an E horizon. We suppose that the pedological and geological conditions on the site (SpirhanzlDuriš, 1929, pp. 125-126) led to the formation of illuviation. The E horizon is situated in the neighbourhood of the village in the northern part of the fields. For example, Søren M. Kristiansen dealt with the relation between podsols (haplic Podsols by WRB, Spodosols by USDA) and agricultural activity in his study (Kristiansen, 2001, pp. 273-289), where, through macroscopic observations, he proved a relationship between the current state of soil horizons and usage of the ground during the Bronze Age on the Alstrup Krat site (2000 BP). Areas which were not or only a little cultivated are now covered with podsols, but intensively-cultivated areas are covered with hyperdystric arenosols (by WRB, Entisols Psamments by USDA). However, the situation in the fields around the deserted village of Spindelbach in Krušné Hory 
(Ore Mountains, Erzgebirge) does not provide evidence of such a relationship (Horák, Klír, 2017).

\section{Conclusion}

The long-term research interest of the Department of Archaeology, Faculty of Arts, Charles University, in the deserted medieval village of Hol has allowed us to combine the humanities and some technical approaches. A geochemical survey of its area is thus only revealing a part of the whole picture. The agricultural base of the village was dependent on its natural conditions, and signs of human activity are clearly identifiable in the areas of the gardens in the northern part of the village. The element content ( $\mathrm{As}, \mathrm{Cu}$, $\mathrm{Fe}, \mathrm{Ni}, \mathrm{P}, \mathrm{Pb}, \mathrm{Zn}, \mathrm{Mn}, \mathrm{Sr}$, and LE) and PCA (PC2, PC3, PC7) show areas that relate to former medieval activities. We do not know, however, whether it was a structural, economic or agricultural activity.

The geochemistry was characterised by a very low content of soil P. We presume there were ineffective manuring practices combined with the short duration of agricultural cultivation. Nevertheless, the soil P content helped us to interpret the area of gardens in the homesteads IX, X and XI, where the presence of wooden constructions for agricultural purposes is presumed based on the $\mathrm{P}$ content measured there.

Agricultural management at Hol was connected with quantities of organic waste and ash from the homesteads (Zn, probably Mn). The spatial distribution of soil content of elements and the PCA allows us to claim that we can differentiate the functional parts of the village based on purely geochemical methods. Generally, the content of measured elements was lower away from the centre of the village. The highest content of the majority of observed elements was found within the village common and in the area of the homesteads.

The village of Hol fell into a crisis during the economic transformations during the Middle Ages and has remained deserted thereafter. The causes of the decline, as in most cases, can be linked to a combination of several causes. The commercialisation of agricultural production between the $14^{\text {th }}$ and $16^{\text {th }}$ century caused growing disparities between the areas with fertile land and those areas with infertile land. This disparity might have been further deepened by the village's rather short distance from the city of Prague. And last, but not least, there was the problem of the mineral exhaustion of the soil, which had been depleted by the inadequate agricultural procedures, which then led to the collapse of the village.

\section{Acknowledgements}

This output was created within the project "Kulturni techniky: materialita, medialita a imaginace" (Cultural techniques: materiality, mediation and imagination), subproject "Středověká ves a její prírodni prostředí.
Mezioborový výzkum zaniklých vsí v zázemí Prahy” (Mediaeval village and its environment: interdisciplinary research of deserted villages in surroundings of Prague) undertaken at Charles University from Specific University Research in 2018. This research was supported by the Charles University Grant Agency, project No. 307415 "New insights on a functional structure of abandoned villages' field systems and on relationship between human activities and environment by way of pedochemical methods"; by Specific University Research project 2017 - 260419, performed at the Faculty of Arts of Charles University; by the GA CR No. 16-20763S "The Landscape of Medieval Prague" and by the Charles University Project Progress No. 3 (Q07), Centre for Medieval Studies.

This paper is dedicated to Viktorie A. Dančová.

We would like to thank Lenka Lisá for useful and inspiring advices and comments.

\section{References}

ASTON, M. A., MARTIN, M. H., JACKSON, A. W., 1998. The use of heavy metal soil analysis for archaeological surveying. Chemosphere, 37, 465-477.

BAKKEVIG, S., 1980. Phosphate Analysis in Archaeology - Problems and Recent Progress. Norwegian Archaeological Review, 13(2), 73-100.

BERÁNEK, M., 2010. Zaniklá vesnice Žák. K problematice raněnovověkých sidelnich forem. Unpublished theses (Bc), Charles University, Prague.

BERÁNEK, M., 2011. Zaniklá vesnice v poloze „V Žáku“v Klánovickém lese (Praha). K problematice plánovitých sídelních forem. Studia Mediaevalia Pragensia, 10(1), 91-204.

BERÁNEK, M., 2013. Vesnické osídleni v zázemí vrcholně a pozdně středověké Prahy. Sidelně-historický vývoj a zemédélství v př́městských oblastech. Unpublished theses (MA), Charles University, Prague.

BUllock, P., FEDEROFF, N., JONGERIUS, A., STOOPS, G., TURSINA, T., BABEL, U., 1985. Handbook for soil thin section description. $1^{\text {st }}$ ed. Wolverhampton: Waine Research Publications.

CANTI, M., HUISMAN, D. J., 2015. Scientific advances in geoarchaeology during the last twenty years. Journal of Archaeological Science, 56, 96108.

CAMPBELL, B. M. S., 2016. The great transition: climate, disease and society in the late-medieval world. $1^{\text {st }}$ ed. Cambridge: Cambridge University Press.

da COSTA, M. L., KERN, D. C., 1999. Geochemical signatures of tropical soils with Archaeological black earth in the Amazon. Brazil. Journal of Geochemical Exploration, 66, 369-385.

DAVIDSON, D. A., WILSON, C. A., MEHARG, A. A., DEACON, C., EDWARDS, K. J., 2007. The legacy of past manuring practices on soil contamination in remote rural areas. Environment International, 33, 78-83.

DEMEK, J., MACKOVČIN, P. (eds.) et al., 2006. Zeměpisný lexikon $\check{C} R$. Hory a nižiny. $2^{\text {nd }}$ ed., Brno: AOPK C̆R.

ENTWISTLE, J. A., ABRAHAMS, P. W., DODGSHON, R. A., 1998. MultiElement Analysis of Soils from Scottish Historical Sites. Interpreting Land-Use History Through the Physical and Geochemical Analysis of Soil. Journal of Archaeological Science, 25, 53-68.

ENTWISTLE, J. A., ABRAHAMS, P. W., DODGSHON, R. A., 2000. The Geoarchaeological Significance and Spatial Variability of a Range of Physical and Chemical Soil Properties from a Former Habitation Site, Isle of Skye. Journal of Archaeological Science, 27, 287-303.

HEJCMAN, M., KARLÍK, P., ONDRÁČEK, J., KLÍR, T., 2013. ShortTerm Medieval Settlement Activities Irreversibly Changed Forest Soils and Vegetation in Central Europe, Ecosystems, 16, 652-663.

HERŠT, V., 1956. Zpráva č. H 17/56 o hydrogeologickém průzkumu na stavební akci číslo zak. Z-63712, evid. zn. 17-0110 - Klánovice. Unpublished report. Czech Geological Survey, Prague. 
HIJMANS, R. J., 2016. raster: Geographic Data Analysis and Modelling. $R$ package version 3.4.1.Available from: https:/CRAN.R-project.org/ package=raster $($ accessed 01.01 .17$)$

HOLLIDAY, V. T., GARTNER, W. G., 2007. Methods of soil P analysis in archaeology. Journal of Archaeological Science, 34, 301-333.

HORÁK, J., KLÍR, T., 2017. Pedogenesis, pedochemistry and the functional structure of the Waldhufendorf field system of the deserted medieval village Spindelbach, the Czech Republic. Interdisciplinaria Archaeologica - Natural Sciences in Archaeology, 8(1), 43-57.

HORÁK, J., JANOVSKÝ, M., HEJCMAN, M., ŠMEJDA, L., KLÍR, T., 2018. Soil geochemistry of medieval arable fields in Lovětín near Třešt', Czech Republic. Catena, 162, 14-22.

HÜRKAMP, K., RAAB, T., VÖLKL, J., 2009. Two and three-dimensional quantification of lead contamination in alluvial soils of a historic mining area using field portable X-ray fluorescence (FPXRF) analysis. Geomorphology, 110, 28-36.

CHÁB, J., STRÁNÍK, Z., ELIÁŠ, M., 2007. Geologická mapa České republiky 1:500 000. $1^{\text {st }}$ ed. Prague: Czech Geological Survey.

JANOVSKÝ, M., 2015. Geochemické metody v archeologii středověku: testování v areálu zaniklé vsi Hol (Hl. m. Praha). Unpublished theses $(\mathrm{Bc})$, Charles University, Prague.

KALNICKY, D. J., SINGHVI, R., 2001. Field portable XRF analysis of environmental samples. Journal of Hazardous Materials, 83, 93-122.

KLÁPŠTĚ, J., 2016. The Archaeology of Prague and the Medieval Czech Lands, 1100-1600. $1^{\text {st }}$ ed. Studies in the Archaeology of Medieval Europe Series, Sheffield: Equinox Publishing.

KLIMEK, K., 2002. Human-induced overbank sedimentation in the foreland of the Eastern Sudety Mountains. Earth Surface Processes and Landforms, 27, 391-402.

KLÍR, T., 2008. Osídleni zemédělsky marginálních půd v mladším stredověku a raném novověku - Besiedlung und landwirtschaftliche Nutzung marginaler Böden im späten Mittelalter und der frühen NeuzeitThe settlements and agriculture of the margins in the later middle age and early new age. Dissertationes Archaeologicae Brunenses/Pragensesque 5, Prague: Faculty of Arts, Charles University.

KLÍR, T., 2010a. Osídlení horských oblastí Čech ve středověku a raném novověku - východiska interdisciplinárního výzkumu. Settlement in Mountainous Areas of Bohemia in the Middle Ages and the Early Modern Age Period - Points of Departure for Interdisciplinary Research. Archaeologia Historica, 35, 373-391.

KLÍR, T., 2010b. Rural settlements in Bohemia in the "age of transition" $\left(14^{\text {th }}-16^{\text {th }}\right.$ century): research concept and preliminary report. Medieval Settlement Research, 25, 52-61.

KLÍR, T., BERÁNEK, M., 2012. A social-economic interpretation of the layouts of deserted villages. An example of a deserted village at the "V Žáku” site in Klánovice Forest in Prague. In: J. Žegklitz, ed. Studies in Post-medieval Archaeology 4. Prague: ARCHAIA Praha o.p.s., pp. 289364.

KLÍR, T., 2013a. Agrarsysteme des vorindustriellen Dorfes. Zur Interpretation mittelalterlicher Ortswüstungen im Niederungs- und Mittelgebirgsmilieu. In: C. Theune, ed. Stadt-Land-Burg. Festschrift für Sabine Felgenhauer-Schmiedt zum 70. Geburtstag. Studia honoraria 34. Leidorf: VML Vlg Marie Leidorf, pp. 139-157.

KLÍR, T., 2013b. A socio-economic interpretation of the regular village layouts in Bohemia and Moravia. In: J. Klápště, ed. Hierarchies in rural settlements. Ruralia 9. Turnhout: Brepols Publishers, pp. 447-462.

KLÍR, T., 2016. Zaniklé středověké vsi ve výzkumném záměru Ústavu pro archeologii Univerzity Karlovy v Praze. Zaniklý Spindelbach (Krušné hory), Kří a Hol (střední Čechy). In: P. Nocuń, K. Fokt, A. PrzybyłaDumin, eds. Wieś zaginiona. Stan i perspektywy badań. Seria: Monografie i materiały MGPE 5, Chorzów, pp. 17-58.

KRISTIANSEN, S. M. 2001. Present-day soil distribution explained by prehistoric land-use: Podzol - Arenosol variation in an ancient woodland in Denmark. Geoderma, 103, 273-289.

KURPElOVÁ, M., COUFAL, L., ČUlíK, J., 1975. Agroklimatické podmienky $\check{C} S S R .1^{\text {st }}$ ed. Bratislava: Príroda.

LEWIS, R. J., FOSS, J. E., MORRIS, M. W., TIMPSON, M. E., STILES, C. A., 1993. Trace element analysis in pedo-archaeology studies. In: J. E. Foss, M. E. Timpson, M. W. Morris, eds. Proceedings of the First International Conference on Pedo-Archaeology. University of Tennessee Press, pp. 81-88.
LIMPERT, E., STAHEL, W. A., ABBT, M., 2001. Log-normal Distributions across the Sciences: Keys and Clues. BioScience, 51, 341-352.

LINDERHOLM, J., LUNDBERG, E., 1994. Chemical characterization of various Archaeological soil samples using main and trace elements determined by inductively coupled plasma atomic emission spectrometry. Journal of Archaeological Science, 21, 303-314.

LISÁ, L., KOMOROCZY, B., VLACH, M., VÁLEK, D., BAJER, A., KOVÁRNÍK, J., RAJTÁR, J., HÜSSEN, C. M., ŠUMBEROVÁ, R., 2015. How were the ditches filled? Sedimentological and micromorphological classification of formation processes within graben-like archaeological objects. Quaternary International, 370, 66-76.

NIELSEN, N. H., KRISTIANSEN, S. M., 2014. Identifying ancient manuring: traditional phosphate vs. multielement analysis of archaeological soil. Journal of Archaeological Science, 42, 390-398.

NOLAN, K. C., REDMOND, B. G., 2015. Geochemical and geophysical prospecting at three multicomponent sites in the Southwestern Lake Erie Basin: A pilot study. Journal of Archaeological Science: Reports, 2, 94-105.

PEBESMA, E. J., 2004. Multivariable geostatistics in S: the gstat package. Computers \& Geosciences, 30, 683-691.

PROFOUS, A., 1947. Mistní jména v Čechách: jejich vznik, pưvodní význam a změny. Díl I. A-H. $1^{\text {st }}$ ed. Prague: Nakladatelství Československé akademie věd, Academia.

QUITT, E., 1971. Klimatické oblasti Československa. $1^{\text {st }}$ ed. Prague: Academia.

R CORE TEAM, 2017. R: A language and environment for statistical computing. R Foundation for Statistical Computing, Vienna, Austria. Available from: https://www.R-project.org/.

REIMANN, C., FILZMOSER, P., GARRETT, R., DUTTER, R., 2008. Statistical Data Analysis Explained. Applied Environmental Statistics with R. John Wiley and Sons. Chichester: John Wiley \& Sons.

REIMANN, C., FILZMOSER, P., FABIAN, K., et al., 2012. The concept of compositional data analysis in practice - Total major element concentrations in agricultural and grazing land soils of Europe. Science of the Total Environment, 426, 196-210.

ROOS, CH. I., NOLAN, K. C., 2012. Phosphates, plowzones, and plazas: a minimally invasive approach to settlement structure of plowed villager sites. Journal of Archaeological Science, 39, 23-32.

SMETÁNKA, Z., 1988. Život středověké vesnice. Zaniklá Svídna. $1^{\text {st }}$ ed. Prague: Academia.

SPIRHANZL-DURIŠ, J., 1929. Půdy okresu Brandýs nad Labem. $1^{\text {st }}$ ed. Prague: Ministerstvo zemědělství republiky Československé.

ŠMEJDA, L., HEJCMAN, M., HORÁK, J., SHAI, I., 2017. Ancient settlement activities as important sources of nutrients $(\mathrm{P}, \mathrm{K}, \mathrm{S}, \mathrm{Zn}$ and $\mathrm{Cu})$ in Eastern Mediterranean ecosystems - The case of biblical Tel Burna, Israel. Catena, 156, 63-72.

TEMPL, M., HRON, K., FILZMOSER, P., 2011. robCompositions: An R-package for robust statistical analysis of compositional data. In: V. Pawlowsky-Glahn, A. Buccianti, eds. Compositional Data Analysis. Theory and Applications. Chichester: John Wiley \& Sons, pp. 341-355.

TOLASZ, R. et al., 2007. Atlas podnebi Česka. Climate Atlas of Czechia. $1^{\text {st }}$ ed. Prague-Olomouc: Czech Hydrometeorological Institute.

TOMÁŠEK, M., 1990. Půdní mapa ČR. List 13-13 (Brandýs n. L-Stará Boleslav), 1:50 000. Prague: Ústřední ústav geologický.

WILSON, C. A., DAVIDSON, D. A., CRESSER, M. S., 2005. An evaluation of multielement analysis of historic soil contamination to differentiate space use and former function in and around abandoned farms. The Holocene, 15, 1094-1099.

WILSON, C., CRESSER, M., DAVIDSON, D., 2006. Sequential element extraction of soils from abandoned farms: an investigation of the partitioning of anthropogenic element inputs from historic land use. Journal of Environmental Monitoring, 8, 439-444.

WILSON, C. A., DAVIDSON, D. A., CRESSER, M. S., 2008. Multi-element soil analysis: an assessment of its potential as an aid to archaeological interpretation. Journal of Archaeological Science, 35, 412-424.

WILSON, C. A., DAVIDSON, D. A., CRESSER, M. S., 2009. An evaluation of the site specificity of soil elemental signatures for identifying and interpreting former functional areas. Journal of Archaeological Science, $36,2327-2334$ 